\title{
Failure of an autotank repaired by welding
}

\section{Fallas de soldadura de reparación de autotanque}

SALGADO-LOPEZ, Juan Manuel†*, OJEDA-ELIZARRARÁS, José Luis, SILVA-HERNANDEZ, Abraham and TELLO-RICO, Jesús Mauricio

ID $1^{\text {st }}$ Author: Juan Manuel, Salgado-Lopez / ORC ID: 0000-0002-2384-1887, CVU CONACYT ID: 94744

ID $1^{\text {st }}$ Coauthor: José Luis, Ojeda-Elizarrarás / ORC ID: 0000-0001-8412-7778, CVU CONACYT ID: 81630

ID $2^{\text {nd }}$ Coauthor: Abraham, Silva-Hernandez / ORC ID: 0000-0003-2699-8107, CVU CONACYT ID: 726099

ID $3^{\text {rd }}$ Coauthor: Jesús Mauricio, Tello-Rico / ORC ID: 0000-0002-5657-2134, CVU CONACYT ID: 586320

DOI: $10.35429 /$ JSTA.2020.17.6.1.9

Received January 25, 2020; Accepted June 30, 2020

\begin{abstract}
The aim of this work is to show that welded vessels, which have been coated by a polymer for overcoming the pneumatic test are susceptible to failure. This is so, because the cyclic load, which are applied in the vessel during its work. This aim was reached by applying different inspections and tests to a vessel manufactured with aluminium plates, which was used to freight. The vessel had to be repaired by welding, but it failed after few cycles of loading/unloading in the repaired weld. The specimen under study was inspected visually and by nondestructive tests. In this sense, the plate with fracture was tested by mechanical stress test, optical emission spectrometry, and metallographic analysis. The fracture surface was inspected by scanning electron microscopy. The results of all the techniques showed that the failure occurred due to coalesce of multiple cracks that grew by the mechanism of fatigue from welding defects. On the fracture surfaces was found evidence of sealing polymer used for the pneumatic pressure test. This work demonstrates that in welding repairing, the metallurgy and the welding engineering are critical to avoid premature failures of welded components.
\end{abstract}

\begin{abstract}
Resumen
El objetivo de este trabajo es dejar en claro que recipientes soldados que han sido recubiertos por un polímero para superar la prueba neumática de presión son susceptibles a fallar cuando son sometidos a cargas cíclicas durante el trabajo. Esto se logró aplicando diferentes inspecciones y ensayos a un autotanque fabricado de placas de aluminio que requirió ser reparado por soldadura y falló en la soldadura de reparación después de algunos ciclos. En el espécimen bajo estudio fue inspeccionado en el sitio visualmente y por medio de prueba no destructiva. En este sentido la placa con la fractura fue ensayada por ensayo mecánico de tensión, espectrometría de emisión óptica, y análisis metalográfico. La superficie de fractura fue inspeccionada por microscopia electrónica de barrido. Los resultados de todas las técnicas demostraron que la falla ocurrió por la incidencia de múltiples grietas que crecieron por el mecanismo de fatiga a partir de defectos de soldadura. En las superficies de fractura fueron encontrados rastros de polímero sellador utilizado para la prueba de presión neumática. Este trabajo demuestra que, en soldadura de reparación, el conocimiento en la metalurgia y la ingeniería de soldadura son críticos para evitar fallas prematuras en uniones reparadas por soldadura.
\end{abstract}

Soldadura, Aluminio, Falla, Fatiga

Citation: SALGADO-LOPEZ, Juan Manuel, OJEDA-ELIZARRARÁS, José Luis, SILVA-HERNANDEZ, Abraham and TELLO RICO, Jesús Mauricio. Failure of an autotank repaired by welding. Journal of Scientific and Technical Applications. 2020. 6-17:1-9.

\footnotetext{
* Correspondence to Author (Email: msalgado@ cidesi.edu.mx)

$\dagger$ Researcher contributing as first author.
} 


\section{Introduction}

In the technical literature it has been reported that flaws in welded components play a very important role in their premature failures; since the combination of workloads with stress risers (as flaws are) leads to crack growth by fatigue or failures due to overload [1-2]. Both cases indicate that defects reduce the load area with which the stress is locally increased and it results in a failure [4-8].

In the other hand, it is common practice in the cast aluminum industry to fill with a polymer cast defects such as shrinkages, connected blows, etc. [9-10]. However, sometimes this practice is applied after welding aluminum components [10-11]. In this work it is shown an example of the problems of such practice in welding repair with a case of the failure of the auto tank's vessel made of aluminum that was repaired in a section (figures 1 and 2).

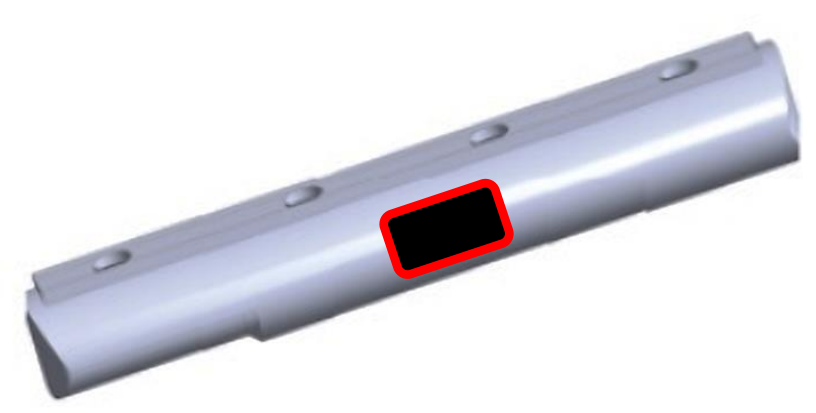

Figure 1 The image shows the failed section of the vessel Source: own work [PDFcreator]

The failed vessel consisted of rings made of aluminum plates. A repair was done on the body of such component and it consisted of a plate welded to the body as a patch. The autotank failure consisted of the separation of the patch plate from one of the sides of the vessel during the filling. It should be noted that the cause of the repair was not the objective of this work, then it was not possible to analyze the previous failure that gave rise to the need for the patch. The failed plate occurred during a polymer loading event and consisted of the detachment of the patch plate, which led to an accident.

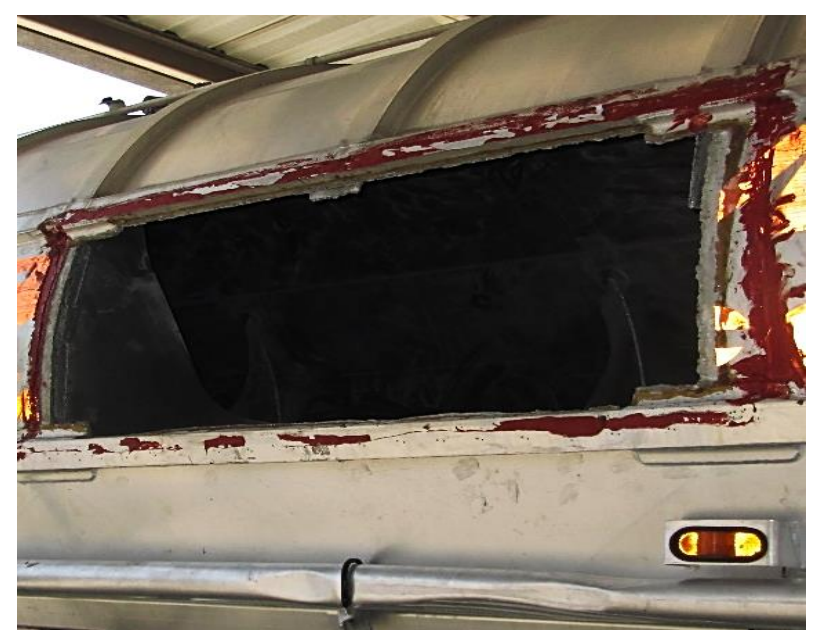

Figure 2 The image shows the original fracture of the vessel and the fracture of the weld joining the patch. Evidence of the polymer placed on the edge of the patch plate (red spot) was found

Source: own work [Canon powershot A3400IS]

This component worked for five years after the repair and there was no technical information about the repairing such as welding procedure (WPS), cause of the need for repair, periods and type of preventive maintenance, types of non-destructive inspections performed, etc., was obtained. The metallurgical cause of the original fracture of the vessel could not be identified because the evidence was erased during the repairing of it.

\section{Methodology}

In order to find the metallurgical reason that led the detachment of the vessel patch, different techniques were applied such as: in situ naked eye visual test. Besides, dye penetrant inspection on the external surface of the vessel was carried out in the location of the failure and the visual inspection in the laboratory using a stereographic microscope.

Mechanical testing of the failed plate was performed following ASTM-E08-16 [12]. Three specimens of the repaired plate were tested using an INSTRON model 4482 universal testing machine. In the case of microhardness profile, measurements of the Vickers microhardness were carried out on a Wilson hardness, Tukon Model 1202 microdurometer. 
The metallographic analysis was carried out with samples, which were cut in the transverse plane to the weld. The samples were prepared to observe the microstructure following ASTM-E03-11. The microstructures were revealed by chemical etching with Kellers reagent. The microstructure was observed using an NIKON EPIPHOT 200 optical microscope with image analyzer.

The fractographic analysis was performed in three different areas of the fracture surface using a JEOL JSM 6610LV scanning electron microscope (SEM) with an EDAX probe for EDS microanalysis. Each fracture surface had the following dimensions: $9 \mathrm{~mm}$ in width and $250 \mathrm{~mm}$ in length. It should be mentioned that the fracture surface samples were cut from the specimen under study by mechanical cutting using coolant.

The results of each technique were analyzed as a whole and from there the metallurgical cause of the failure was found.

\section{Results and discussion}

As previously noted, the objective of this work was to determine the metallurgical causes that led to the fracture and detachment of the vessel repair plate and to show that filling with polymer the welding flaws does not avoid failures. In this section there are shown the most important results.

In situ vvisual test was carried out on the failed vessel and it showed that the failure was a crack that grew following the weld metal of the aluminum plate that served as a patch on the vessel, which was detached during the loading process. Similarly, the visual inspection probed that there was evidence of welding flaws such as aligned porosity, undercuts, lacks of fusion, etc. This fact matches with the evidence that the crack grew following the weld toe, either at the foot of the weld bead or in the middle of the weld metal (Figures 3 and 4). This fact indicates that welding defects played an important role in the failure of the vessel patch plate [12-17].

On the other hand, it should be noted that evidence of resin was found on the welded joints of the vessel. In addition, this evidence of resin was observed throughout the outer and inner surfaces of the weld metal.

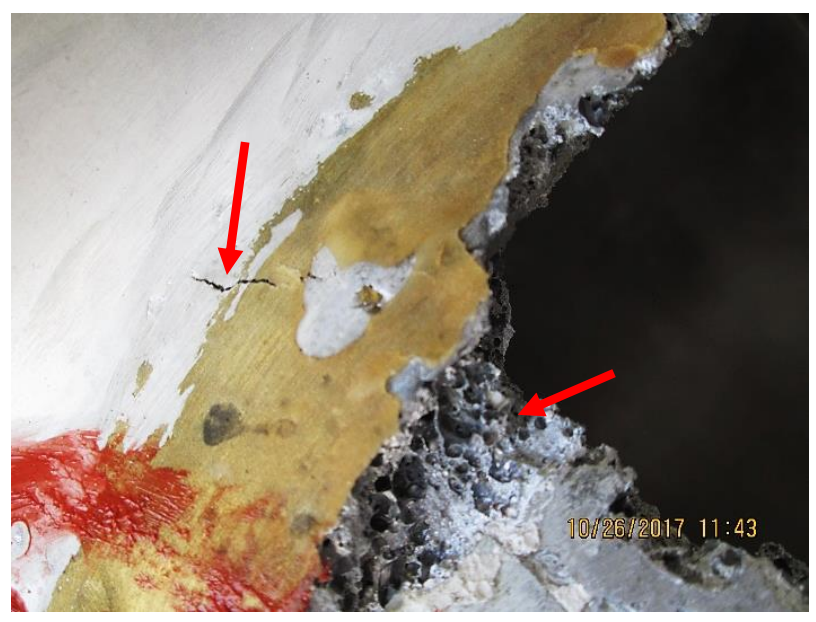

Figure 3 The image shows the fracture surface of the repair welding, there is evidence of polymer and porosity Source: own work [Canon powershot A3400IS]

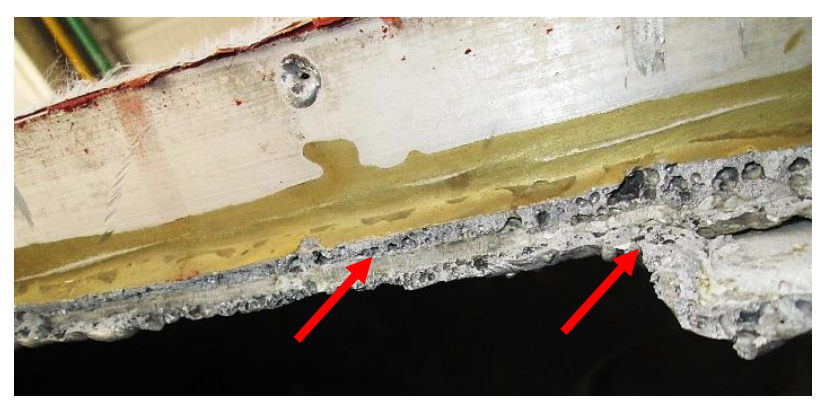

Figure 4 The image shows more evidence of the polymer on the weld metal and porosity on the crack

Source: own work [Canon powershot"A3400IS]

No information was found about the nondestructive tests that were carried out after repairing neither the preventive maintenance. This information is important because it gives a technical frame about the defects found in the weldment and if they grew with the loading / unloading cycles of the vessel [17-18].

The visual test in the vessel showed evidence of repairs away the failed patch.The Dye penetrant test that carried out on the external surface of the welding of the vessel indicated that there were flaws such as undercuts (figure 5 and 6) but there was no evidence of crack growth of the defects located on the weld metals of such repairs. This evidence meant that this vessel did not suffer from any excessive pressure. This fact matched with the Dye penetrant test performed on the surface patch in the upper part of the vessel, where no evidence of overpressure damage was found [19]. 


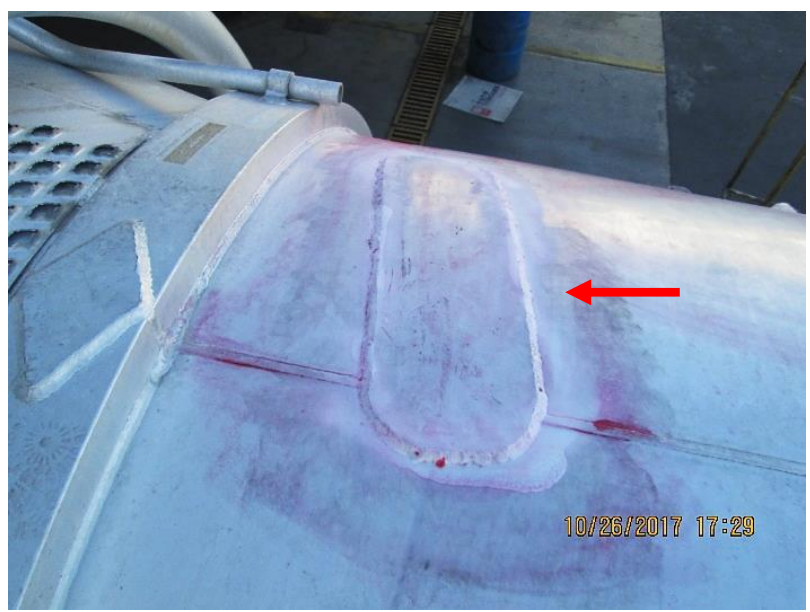

Figure 5 The image shows the results of the inspection by penetrating liquids in a previous repair by welding of the failed vessel. No indications are observed

Source: own work [Canon powershot A3400IS]

The visual testing carried out on the specimens delivered to the laboratory showed that the fracture of the patch plate grew following the weld seam, either at the toe or in some cases in the middle of the deposited metal. These evidences clearly indicated that the fracture of this component was due to flaws in the welded joint. This fact demonstrates the importance of welding procedure specification (WPS) and the manufacturing records, in order to discover possible divergences between the procedure and the actual joint.

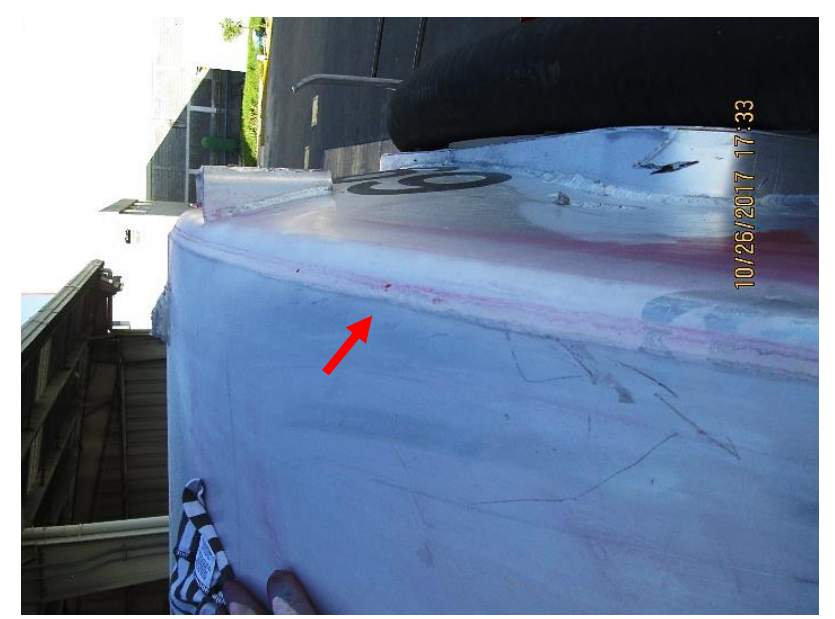

Figure 6 The image shows the results of the inspection by penetrating liquids in a previous repair by welding of the failed hopper. No indications were observed

Source: own work [Canonpowershot A3400IS]

Even though the laboratory requested technical information or the evidence of the nondestructive inspections carried out both in the preventive maintenance and after the repair welding process, the vessel's owner had no information. Therefore, it was not possible to correlate the welding procedure (WPS) to the evidence found in this service.
Visual testing in the laboratory using a stereographic microscope confirmed the existence of defects such as porosity, lack of fusion and incomplete penetrations along the weld seams present in the patch plate of the vessel under analysis (figures 7 and 8). This also applies to welded joints of the internal reinforcements of the patch plate. This evidence is very important because it indicated that the welding process of both welds were performed in not the best way [19].

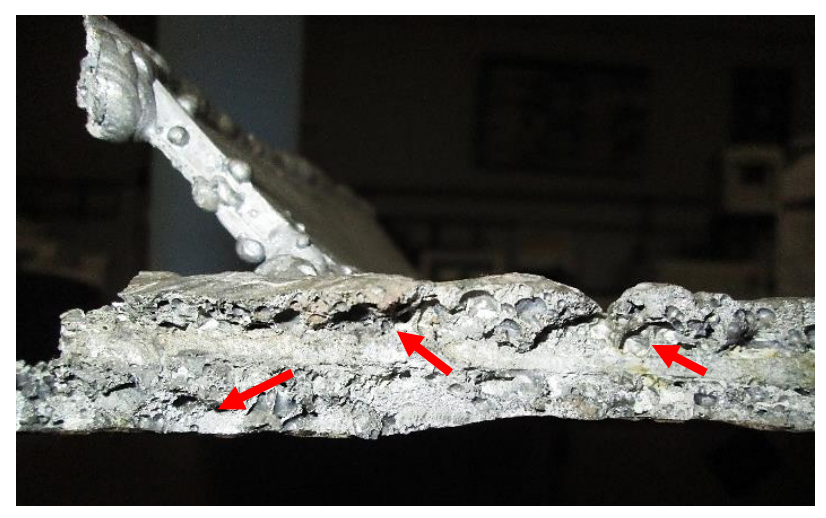

Figure 7 The image shows the fracture surface. Porosity is observed as well as fracture grew along the weld seam Source: own work [Canon powershot A3400IS]

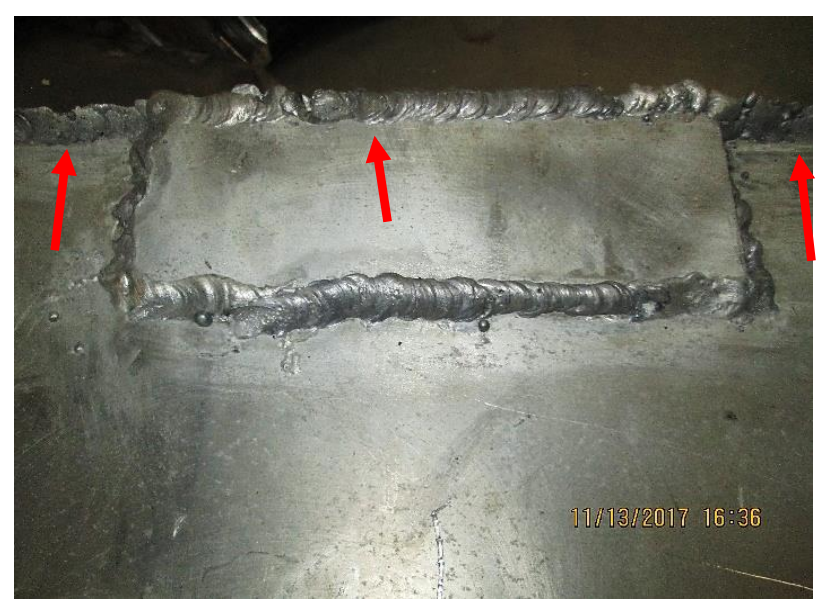

Figure 8 The image shows 7X that the fracture grew along the weld seam

Source: own work [Canon powershot A3400IS]

Another very important evidence was revealed by the inspection using a stereographic microscope. This evidence was fatigue marks in many regions of the weld bead (Figure 9). This fact is important because it confirmed that in the failure of this welded joint occurred by fatigue but several regions with origins of fatigue marks indicated the existence of multiple origins of the fracture. In this way, it was remarkable that all fatigue origins were located in welding defects such as incomplete fusion or aligned porosity [67]. These facts were confirmed by the inspection using SEM.

SALGADO-LOPEZ, Juan Manuel, OJEDA-ELIZARRARÁS, José Luis, SILVA-HERNANDEZ, Abraham and TELLO RICO, Jesús Mauricio. Failure of an autotank repaired by welding. Journal of Scientific and Technical Applications. 2020 


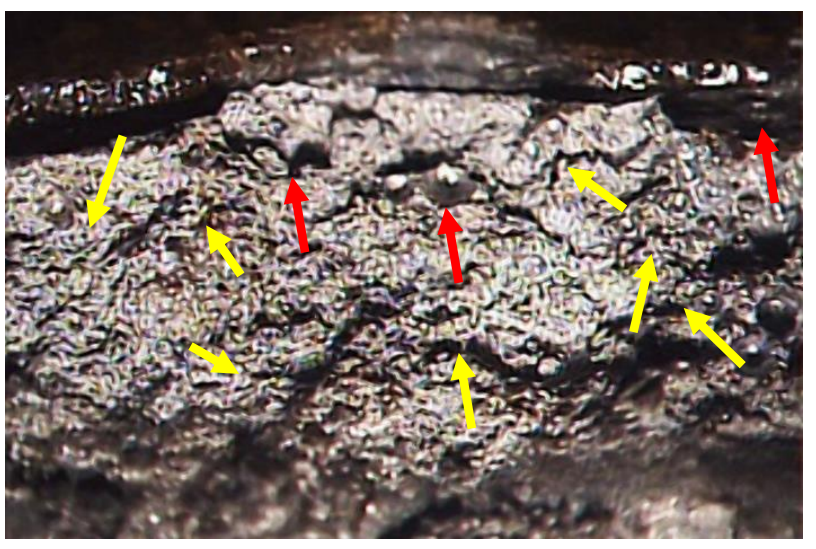

Figure 9 The image shows the fracture surface at 10X. Porosity and fatigue marks (yellow arrows) are observed. There is seen three cracks origin (red arrows)

Source: own work [Leica stereoscope]

Through the inspection by Scanning Electron Microscopy (SEM) on the fracture surfaces of the fractured specimens the existence of fatigue striations was demonstrated. This fracture pattern proved that the cracks grew due to the fatigue mechanism (Figure 10). However, there was not a single crack origin but several, so it was not possible to determine the origin of the primary crack. This evidence matched with the information about the four year work of this vessel after the repair of the vessel with a patch plate. This working time is reflected in the number of fatigue cycles and the fact that weld metal failed in the last loading event indicated that the final fracture was caused by the classic plastic collapse in fatigue failures.

In this same sense, in the fracture surfaces evidence of polymer was found in the porosity detected (figures 10 and 11), this fact indicated that the fracture surface was in contact with the polymer powders before the final failure of the patch plate occurred. If one takes into account that the polymer was only housed inside the vessel then it is feasible that the crack grew for four years and the weld collapsed in the last material loading event [20-23].

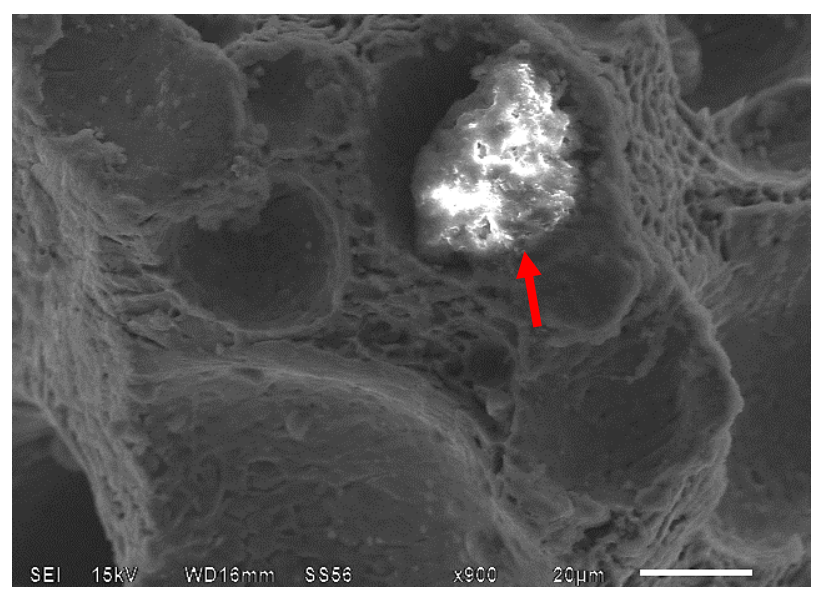

Figure 10 The SEM image shows striations due to fatigue and evidence of trapped inclusions

Source: own work [JEOL JSM 6610L]

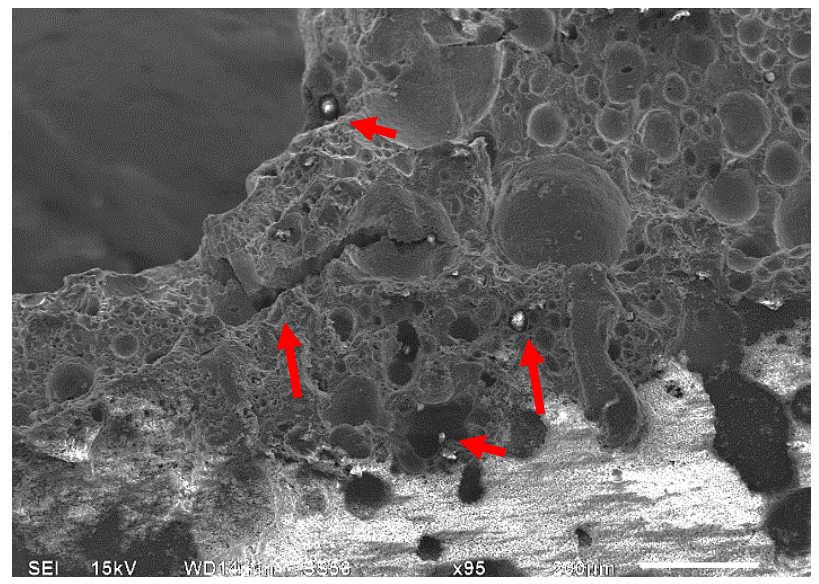

Figure 11 The SEM image shows evidence of organic matter trapped between the fracture dimples Source: own work [JEOL JSM 6610LV]

In the case of the Energy Dispersive Xray Spectroscopy microanalysis (EDS) performed in cross-section sample of the weld metal prepared for metallography. There was found evidence of a trapped inclusions (figure 12), the EDS results indicated that it was aluminum oxide (figure 13), whereby this trapped alumina originated in the preparation of the welded joint. In the literature it has been reported that the most common causes of porosity in aluminum welding are: contamination on the surface to be welded, the poor preparation of the parts to be joined, the inadequate application of protective gas, applying welding dragging to the weld metal, to use a carbon steel bristle brush to clean the surfaces to be welded $[3,6]$. 


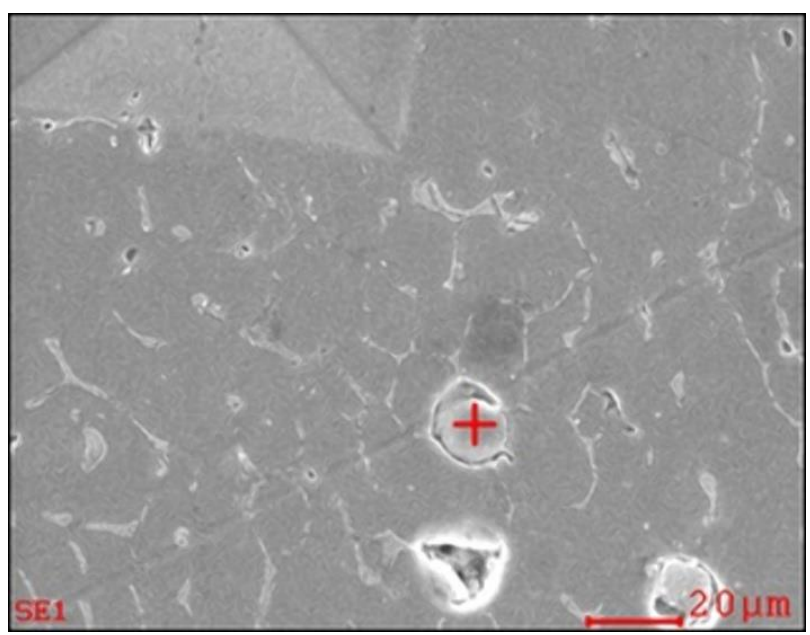

Figure 12 The SEM image shows a trapped particle in the microstructure of the weld metal were EDS microanalysis was carried out

Source: own work [EDAX AMETEK]

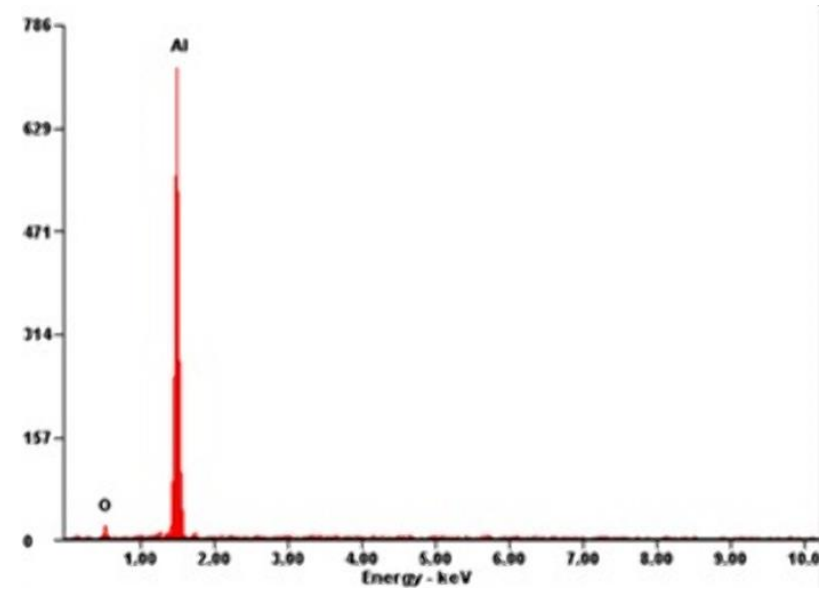

Figure 13 The image shows the results of the EDS microanalysis performed on one of the inclusions trapped in the weld bead

Source: own work [EDAX AMETEK"]

The macrostructural analysis performed on the welded joint probed the existence of welding defects and non-efficient joint design (figure 14). Similarly, it is clear that aligned porosity located on the surface of the weld metal was covered by a polymer layer (Figure 14).

These evidences indicated that the polymer coating (resin) should have been applied as a measure to prevent fluid leakage from inside the vessel, with which the weld inspection accepted the welding.

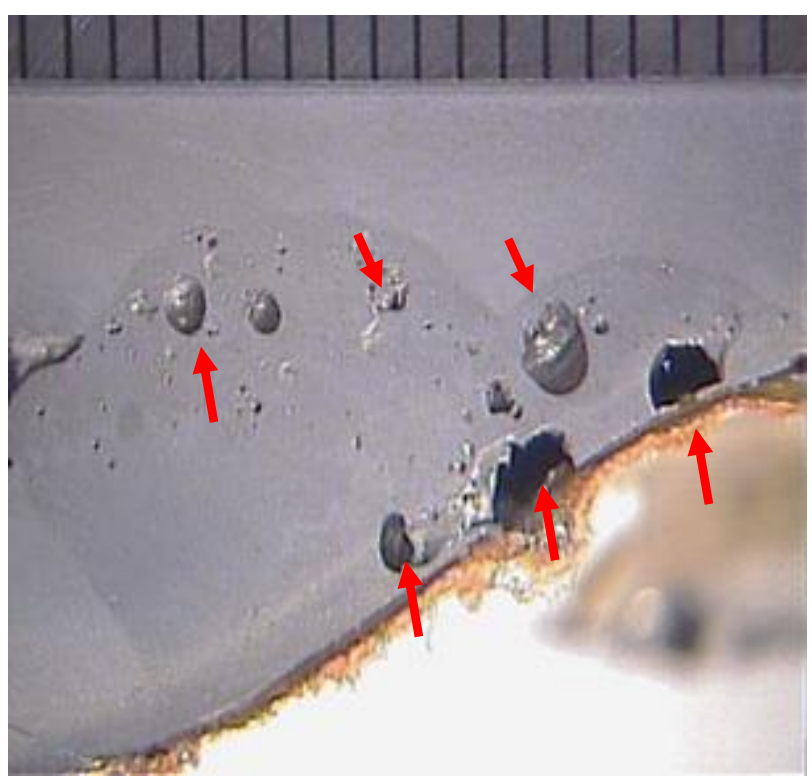

Figure 14 The image shows a cross section of the welded joint failed

Source: own work [Leica Stereoscope]

On the other hand, microstructural analysis showed the existence of dendrites and interdendritic precipitates, in addition to porosity of different dimensions in the microstructure of the weld metal (figure 15).

In the case of the microstructure of the Heat Affected Zone (HAZ), it is seen the existence of metallic precipitates of different types both in the grain boundaries and inside the grains. In fact it can be observed growth precipitates. This type of microstructure is consistent with the welding microstructures of precipitation hardenable aluminum alloys that have been welded (Figure 15).

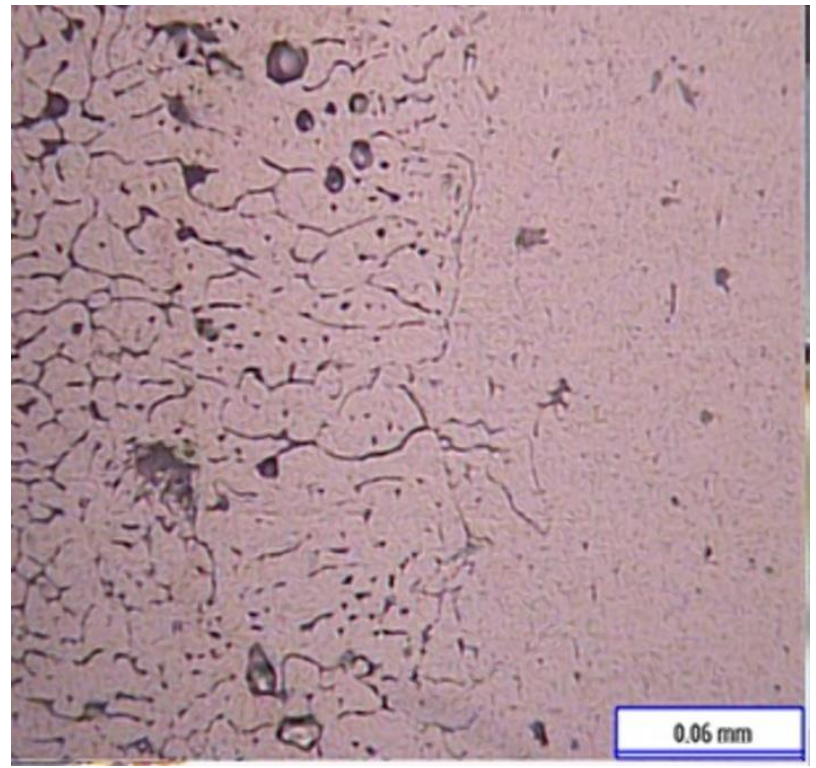

Figure 15 The micrograph shows 500X the microstructure of the ZAT. Dendrites are observed more precipitous interdendritic and porosity Source: own work [Nikon Epiphot]

SALGADO-LOPEZ, Juan Manuel, OJEDA-ELIZARRARÁS, José Luis, SILVA-HERNANDEZ, Abraham and TELLO RICO, Jesús Mauricio. Failure of an autotank repaired by welding. Journal of Scientific and Technical Applications. 2020 
This matches with the quantitative chemical analysis that showed that the patch plate material is similar to that specified in the standard chemical composition of an AISI 5052 aluminum alloy.

In the case of mechanical properties, the results indicate that according to ASTM B290M this 5062 aluminum alloy the mechanical properties matched with an alloy 5052 in condition $\mathrm{H} 32$ that was hardened by rolling and then stabilized by heat treatment from aged to low temperature up to a quarter of hardness. Table 1 shows the average values of the tensile test. Table 2 shows the average microhardness profile measured in the HAZ of the failed specimen. There is seen the variation of microhardness from the weld metal into the base metal.

In this case non relevant information for the fracture of the material was obtained by the mechanical test or the microhardness profile; then no further discussion was done.

\begin{tabular}{|l|c|r|}
\hline \multicolumn{2}{|c|}{$\begin{array}{c}\text { Laboratory } \\
\text { results } \\
\text { (average) }\end{array}$} & $\begin{array}{c}\text { ASTM B209M- } \\
\mathbf{5 0 5 2} \text { H32 }\end{array}$ \\
\hline $\begin{array}{l}\text { Ultimate tensile } \\
\text { strength }\end{array}$ & $225.26 \mathrm{MPa}$ & $215-265 \mathrm{MPa}$ \\
\hline Yield strength & $169.62 \mathrm{MPa}$ & $163 \mathrm{MPa}$ max. \\
\hline Elongation & $17.35 \%$ & $7 \%$ min. \\
\hline
\end{tabular}

Table 1 Mechanical properties of the base metal [ Instron 4482]

Source: prepared by the authors [ËXCEL2013]

\begin{tabular}{|r|c|r|}
\multicolumn{3}{|c}{ Hv in HAZ } \\
Indentation & \multicolumn{1}{|c|}{ Hv } & HR15T \\
\hline 1 & 77.5 & 71.2 \\
\hline 2 & 67.2 & 66.6 \\
\hline 3 & 81.1 & 72.5 \\
\hline 4 & 76.3 & 70.6 \\
\hline 5 & 70.2 & 68.1 \\
\hline 6 & 72.6 & 69.3 \\
\hline 7 & 69.8 & 67.9 \\
\hline 8 & 70.3 & 68.1 \\
\hline 9 & 70.3 & 68.1 \\
\hline 10 & 70.3 & 68.1 \\
\hline & 72.6 & 69.1 \\
\hline
\end{tabular}

Table 2 Average Microhardness profile of the HAZ [Model Tukon 1202]

Source: prepared by the authors [Excell 2013]

\section{Appendage}

All tables and figures were obtained by the Authors in the laboratory for metallography and failure analysis of CIDESI in Queretaro, Mexico.

In addition, the authors wish to thank CIDESI for the support provided during this work.

\section{Conclusions}

The previously discussed facts lead to the following conclusions:

1. The fracture of the component occurred only in the weld metal that connected the patch plate with the vessel.

2. There were multiple origins of cracks.

3. The cracks grew by fatigue.

4. This mechanism was originated in the flaws of the welded joint.

5. The material was characterized and with it was determined that the material of the vessel patch consists of an AISI 5052 aluminium alloy having an $\mathrm{H} 32$ heat treatment.

6. There was found evidence of polymer in the weld metal and in the crack.

7. The polymer applied for filling welding flaws did not increased the fatigue resistance of the welded joint.

\section{References}

1. Rudzey, G. F. (2014). Effect of welding defects and the number of repair passes on the fatigue resistance of welded joints in aluminium alloys. Welding International, 28(11), 907-909. 
2. Dewan, M. W., Wahab, M. A., \& Okeil, A. M. (2014, June). Effect of Weld Defects on Tensile Properties of Lightweight Materials and Correlations with Phased Array Ultrasonic Nondestructive Evaluation. In ASME 2014 International Manufacturing Science and Engineering Conference collocated with the JSME 2014 International Conference on Materials and Processing and the 42nd North American Manufacturing Research Conference (pp. V002T02A068-V002T02A068). American Society of Mechanical Engineers.

3. Chandra, K., \& Kain, V. (2013). Welding failure of as-fabricated component of aluminum alloy 5052. Engineering Failure Analysis, 34, 387-396.

4. Zhang, Z., Yang, X., Zhang, J., Zhou, G., Xu, X., \& Zou, B. (2011). Effect of welding parameters on microstructure and mechanical properties of friction stir spot welded 5052 aluminum alloy. Materials \& Design, 32(8-9), 4461-4470.

5. Li, Y., Yan, F., Luo, Z., Chao, Y. J., Ao, S., \& Cui, X. (2015). Weld growth mechanisms and failure behavior of three-sheet resistance spot welds made of 5052 aluminum alloy. Journal of Materials Engineering and Performance, 24(6), 25462555.

6. Lundin, C. D. (1976). The Significance of Weld Discontinuities-A Review of Current Literature. Welding Research Council Bulletin, (222).

7. Nelson, F. G., \& Holt, M. (1971). Effect of Discontinuities on Weld Strength of Aluminum Alloys. Welding Journal, 50(10), S427.

8. Rajkolhe, R., \& Khan, J. G. (2014). Defects, causes and their remedies in casting process: A review. International Journal of Research in Advent Technology, 2(3), 375383.
9. Koob, S. P. (2003). Tips and Tricks with Epoxy and Other Casting \& Molding Materials. Objects Specialty Group Postprints, 10, 158-172.

10. Patil, P. S. (2017). Repairing Casting Defects by High Pressure Cold Spraying Method.

11. Cosham, A., \& Kirkwood, M. (2000, October). Best practice in pipeline defect assessment. In Proceedings of IPC.

12. Salam, I., Muhammad, W., \& Ejaz, N. (2016, August). Fatigue crack growth in an aluminum alloy-fractographic study. In $I O P$ Conference Series: Materials Science and Engineering (Vol. 146, No. 1, p. 012010). IOP Publishing.

13. Kaufman, J. G., Bucci, R. J., \& Kelsey, R. A. (1980). Fracture mechanics aspects of the structural integrity technology of spherical aluminum containment vessels for LNG tankers. Journal of Engineering Materials and Technology, 102(3), 303-314.

14. Wintle, J. B., \& Pargeter, R. J. (2005). Technical failure investigation of welded structures (or how to get the most out of failures). Engineering Failure Analysis, 12(6), 1027-1037.

15. Nordmark, G. E., Herbein, W. C., Dickerson, P. B., \& Montemarano, T. W. (1987). Effect of weld discontinuities on fatigue of aluminum butt joints. Journal of Welding, 66(6), 162-173.

16. Jones, R., Barter, S., Molent, L., \& Pitt, S. (2005). Crack patching: an experimental evaluation of fatigue crack growth. Composite structures, 67(2), 229238.

17. Barter, S., Molent, L., Goldsmith, N., \& Jones, R. (2005). An experimental evaluation of fatigue crack growth. Engineering failure analysis, 12(1), 99-128. 
18. Wang, P. C., Chisholm, S. K., Banas, G., \& Lawrence Jr, F. V. (1995). The role of failure mode, resistance spot weld and adhesive on the fatigue behavior of weldbonded aluminum. Welding JournalIncluding Welding Research Supplement, 74(2), 41s.

19. Dickerson, P. B. (1986). Quality control in aluminum arc welding. JOM, 38(5), 47-51.

20. Polyakov, V. V., Kolubaev, E. A., Salita, D. S., Dmitriev, A. A., \& Lependin, A. A. (2015, October). Fracturing behavior of aluminum alloys with welded joints. In $A I P$ Conference Proceedings (Vol. 1683, No. 1, p. 020186). AIP Publishing.

21. Borrego, L. P., Costa, J. M., Antunes, F. V., \& Ferreira, J. M. (2010). Fatigue crack growth in heat-treated aluminium alloys. Engineering Failure Analysis, 17(1), 11-18.

22. Leibovich, H., Sasson, N., Simon, A., \& Green, A. K. (1993). Repair of Cracked Aluminum Aircraft Structure with Graphite/Epoxy Patches. In Proceedings of the Ninth International Conference on Composite Materials: ICCM-9: Composites Design (Vol. 4). Woodhead Publishing.

23. Ong, C. L., \& Shen, S. B. (1992). The reinforcing effect of composite patch repairs on metallic aircraft structures. International journal of adhesion and adhesives, 12(1), 19-26. 


\title{
Neurotoxic effect of non-functionalized carbon nanospheres
}

\section{Efecto neurotóxico de las nanoesferas de carbono no funcionalizadas}

\author{
KASHINA, Svetlana†', FLORES-VILLAVICENCIO, Lerida Liss“", JACOBO-AZUARA, Araceli` and \\ GALINDO, Rosario*"'”
}

'Universidad de Guanajuato, Division of Natural and Exact Sciences, Department of Chemistry.

"Universidad de Guanajuato, Division of Natural and Exact Sciences, Department of Biology.

"' CONACYT Chair at the Universidad de Guanajuato, Division of Natural and Exact Sciences.

ID $1^{\text {st }}$ Author: Svetlana, Kashina / ORC ID: 0000-0003-4277-2060, CVU CONACYT ID: 516653

ID $1^{\text {st }}$ Coauthor: Lerida Liss, Flores-Villavicencio / ORC ID: 0000-0001-6349-6005, CVU CONACYT ID: 38686

ID $2^{\text {nd }}$ Coauthor: Araceli, Jacobo-Azuara / ORC ID: 0000-0003-0967-1858, CVU CONACYT ID: 104385

ID $3^{\text {rd }}$ Coauthor: Rosario, Galindo / ORC ID: 0000-0002-3612-1555, CVU CONACYT ID: 223987

\begin{abstract}
Objective. Different types of nanoparticles, including carbon ones, were tested for a variety of biological applications. Alongside with promising results, some undesired side effects were disclosed. Most biological studies were performed on highly functionalized carbon nanospheres, so the main objective of this study was to assess cytotoxicity of unfunctionalized carbon nanospheres synthetized by sol-gel method. We hypothesize that unfunctionalized material will present different cytotoxic pattern on cell culture. Methodology. 3 carbon nanosphere materials were synthetized by sol-gel method. Particles shape, size and functionalization were assessed. Cytotoxic effect of synthesized materials was evaluated on SH-SY5Y cell line using XTT and crystal violet assays and imaging. Contribution. In this work we have demonstrated that cytotoxic effect of carbon nanospheres can be attenuated by varying the conditions of synthesis.
\end{abstract}

\section{Resumen}

Objetivo. Diferentes tipos de nanopartículas, incluidas las de carbono, han sido analizadas para una gran variedad de aplicaciones biológicas. Si bien, los resultados han sido mayoritariamente prometedores, se revelaron algunos efectos secundarios no deseados. La mayoría de los estudios biológicos se realizaron en nanoesferas de carbono altamente funcionalizadas, por lo que el objetivo principal de este estudio fue evaluar la citotoxicidad de las nanoesferas de carbono sin funcionalizar y sintetizadas por el método sol-gel. Inferimos que el material no funcionalizado presentará un patrón citotóxico en el cultivo celular. Metodología. Se sintetizaron 3 materiales de nanoesferas de carbono por el método sol-gel. Se evaluó la diferencia en propiedades como forma y tamaño. El efecto citotóxico de los materiales sintetizados se evaluó en la línea celular SH-SY5Y utilizando ensayos XTT y cristal violeta y por el análisis estructural de organelos. Contribución. Se demostró que el efecto citotóxico de las nanoesferas de carbono puede atenuarse variando las condiciones de síntesis.

Nanoesferas de carbono, Neurotoxicidad, Sol-gel

Citation: KASHINA, Svetlana, FLORES-VILLAVICENCIO, Lerida Liss, JACOBO-AZUARA, Araceli and GALINDO, Rosario. Neurotoxic effect of non-functionalized carbon nanospheres. Journal of Scientific and Technical Applications. 2020. 6-17:10-13.

\footnotetext{
* Correspondence to Author (Email: mr.galindo@ugto.mx)

$\dagger$ Researcher contributing as first author.
} 